\title{
Height categories as a healthier alternative to weight categories in taekwondo competition
}

\author{
Ana DE LA FUENTE* \\ CDE Sánchez Élez - Sanabria Taekwondo Club (Spain)
}

Recepción: 25/01/2018; Aceptación: 24/06/2018; Publicación: 26/06/2018.

\begin{abstract}
Weight division is the most common way of categorizing athletes for competition in martial arts and combat sports. Eating disorders and the use of rapid weight loss methods are common among combat sports athletes, both at young and adult ages at all competition levels. Meanwhile, height is commonly regarded as determinant in kicking combat sports. The present study aimed to examine whether height categories can be used as a healthier alternative to weight categories for official competition. The height and weight of 153 male $(n=80)$ and female $(n=73)$ competitive taekwondo athletes aged between 10 and 16 were measured. Participants were classified by age, sex, and official weight category. Athletes were then sorted into ten hypothetical numbered height categories established in every age and sex group, according to World Health Organization (WHO) percentiles. There was a strong correlation between height and weight $(r=0.843$, $p<0.01)$, and between height and weight categorization ( $r=0.681, p<0.01)$, and $68.18 \%$ of participants stayed the same, or moved only \pm 1 category by height from their original weight category. We conclude that young competitive taekwondo athletes can be categorized by height in official competition, as a healthier and more equitable alternative to the current weight divisions.
\end{abstract}

Keywords: Taekwondo; combat sports; weight loss; martial arts; performance.

\section{Categorías por altura como alternativa más saludable a las categorías de peso para la competición de taekwondo}

\section{Resumen}

La división por pesos es la forma más extendida de clasificar a los atletas para la competición en la mayoría de las artes marciales y deportes de combate. Los trastornos de la conducta alimentaria y la utilización de métodos rápidos de pérdida de peso son comunes entre los atletas de deportes de combate, tanto en edades jóvenes como adultas y en todos los niveles de competición. Además, la altura es considerada generalmente como un factor determinante en los deportes de combate. El presente estudio tuvo como objetivo examinar si las categorías de altura se podrían utilizar como una alternativa más saludable a las categorías de peso en competiciones oficiales. Se midió la altura y el peso de 153 atletas de taekwondo competitivo masculino $(n=80)$ y femenino $(n=73)$, con edades comprendidas entre los 10 y los 16 años. Los participantes se clasificaron según edad, género y categoría de peso oficial. Seguidamente los atletas se clasificaron en diez hipotéticas categorías numeradas de altura, establecidas para cada grupo de edad y género, según los percentiles de la Organización Mundial de la Salud (OMS). Existió una fuerte correlación entre la estatura y el peso $(r=0,843, p<0,01)$ y entre la categoría de altura y de peso $(r=0,681, p<0,01)$, y el $68,18 \%$ de los participantes permanecieron igual, $o$ se movieron únicamente \pm 1 categoría de altura en relación a su categoría de peso original. Concluimos que los atletas jóvenes de taekwondo competitivo se pueden clasificar por

\section{Categorias de altura como alternativa mais saudável às categorias de peso para a competição de taekwondo}

\section{Resumo}

A divisão por pesos é a forma mais aplicada para se classificar os atletas para a competição na maioria das artes marciais e desportos de combate. Os problemas da conduta alimentar e a utilização de métodos rápidos de perda de peso são comuns entre os atletas dos desportos de combate, tanto em idades jovens, como adultas, e em todos os níveis de competição. Por outro lado, a altura é considerada, geralmente, como um fator determinante nos desportos de combate. O presente estudo teve como objetivo examinar se as categorias de altura se poderiam utilizar como uma alternativa mais saudável às categorias de peso em competições oficiais. Mediu-se a altura e pesaram-se 153 atletas de taekwondo competitivo masculino $(n=80)$ e feminino $(n=73)$, com idades compreendidas entre os 10 e os 16 anos. Os participantes foram classificados segundo a idade, género e categoria de peso oficial. Seguidamente, os atletas foram classificados em dez hipotéticas categorias numeradas pela altura, estabelecidas para cada grupo de idade e género, segundo percentil da Organização Mundial de Saúde (OMS). O estudo permitiu constatar que existe uma forte correlação entre a estatura e o peso $(r=0.843, p<0.01)$ e entre a categoria de altura e peso $(r=0.681, p<0.01)$, e $68,18 \%$ dos participantes permaneceram iguais ou se moveram unicamente \pm 1 na categoria de altura em relação à sua categoria de peso original. Concluímos que os atletas jovens de taekwondo competitivo se podem classificar por

* CDE Sánchez Élez - Sanabria Taekwondo Club, Olimpia Sporthall, c/ Cobre 12, Leganés, Spain. E-mail: ana.delafuente@hotmail.com 
estatura para las competiciones oficiales, como una alternativa más saludable y equitativa respecto a las categorías actuales de peso.

Palabras clave: Taekwondo; deportes de combate; pérdida de peso; artes marciales; rendimiento. estatura para as competições oficiais como uma alternativa mais saudável e equitativa relativamente às categorias atuais de peso.

Palavras-chave: Taekwondo; desportos de combate; perda de peso; artes marciais; rendimento.

\section{Introduction}

Taekwondo (TKD) is an Olympic combat sport whose competition events are regularly organized according to athletes' age, sex, and weight divisions. This weight categorizing is very common in most types of combat sports and martial arts, with the aim that athletes compete against opponents with similar physical characteristics, making the fights more equitable. However, combat sports athletes usually aspire to fight in a lighter weight category than their normal weight during the training period, in order to get some advantage over their opponents in terms of body mass, size, strength, and agility (Franchini, Brito, \& Artioli, 2012; Kazemi, Rahman, \& De Ciantis, 2011; Langan-Evans, Close, \& Morton, 2011; Reale, Slater, \& Burke, 2017).

For this reason, the use of rapid weight loss strategies before competitions is extensively practiced in such sports, reaching levels of between 75-90\% of athletes of both international and national level (Franchini et al., 2012; Silva Santos, Takito, Artioli, \& Franchini, 2016). These methods include the use of laxatives or diuretic drugs, wearing plastic clothes, and having sauna sessions. Athletes initiate these procedures at pubertal ages (Constantini, Mashiach, Arieli, \& Dubnov-raz, 2011; Dubnov-Raz, Mashiach-Arazi, Nouriel, Raz, \& Constantini, 2015; Franchini et al., 2012; Langan-Evans et al., 2011). Pre-competition weight loss has been reported regarding $3 \%$ and $7 \%$ of total athlete body mass (Silva Santos et al., 2016).

The negative effects of this rapid weight loss on athletes' health have been thoroughly studied. Psychologically, rapid weight loss procedures can induce decreased short-term memory, difficulty in concentration, enhanced fatigue and confusion, anxiety, decreased vigor, and even depression and isolation (Franchini et al., 2012; Kazemi et al., 2011; Koral \& Dosseville, 2009; Steen \& Brownell, 1990). In physiological terms, rapid weight loss can lead to a dehydration state which produces a decreased plasma volume and hydroelectric disturbances, and some other disorders such as increased heart rate, muscle glycogen depletion, impaired immunity, and altered thermoregulation (Franchini et al., 2012). There have been even some cases of death related to these practices (Franchini et al., 2012; Kazemi et al., 2011; Langan-Evans et al., 2011).

Anthropometric factors such as body composition have been identified as performance predictors in TKD competition. This can be because, as categories are divided by weight, athletes desire to achieve the minimal percentage of fat mass in benefit of muscle mass and thus optimize the power-to-weight ratio (Bridge, Ferreira Da Silva Santos, Chaabène, Pieter, \& Franchini, 2014). However, using rapid weight loss methods to accomplish this improvement of body composition can cause negative effects on sports performance, contrary to the athlete's desire and thus losing this possible advantage. Rapid weight loss can decrease both aerobic and anaerobic performance, decrease lean body mass, worsen contractile capacity (and so power), and increase fatigue, perceived effort, mental tension, and risk of injuries (Dubnov-Raz et al., 2015; Franchini et al., 2012; Kazemi et al., 2011; Langan-Evans et al., 2011; Steen \& Brownell, 1990); all of this is related to the physiological and psychological effects described above. On the other hand, body mass changes due rapid weight loss comparing winners and non-winners was not significant, so rapid weight loss is not a factor affecting performance (Kazemi et al., 2011).

In addition, these practices imply constant attention to body mass control, increasing the probability of eating disorders, for which pubertal ages are the riskiest period and coincide with the age of onset of rapid weight loss practices (Constantini et al., 2011; Dubnov-Raz et al., 2015; Franchini et al., 2012; Klump, 2014).

Weight categories were initially established resembling traditional wrestling culture, attending to the idea that body mass should be similar between both athletes in order to ensure that body manipulation of one against each other is balanced. However, in striking sports as TKD, 
the techniques used do not necessarily include manipulation of the opponent's body mass, but rather specific techniques are based on one's own body mass movement. Thus, some authors point to this practical difference to affirm that body mass plays a less important role in striking sports (Reale, Slater, \& Burke, 2016; Reale et al., 2017). Also, transferring the initial idea to kicking sports, perhaps the generation of different kicking forces (power) between athletes with different body mass can be a possibility, because they have more mass to accelerate. However, previous studies like Estevan, Falco, Álvarez and Molina-García (2012) and Falcó, Estevan, Álvarez and MolinaGarcía (2011) have reported that athletes of different weight divisions do not generate significantly different impact forces in kicking actions.

Height is generally considered as advantageous in kicking combat sports, especially in TKD (Bridge et al., 2014; Reale et al., 2017). Theoretically, a longer lower limbs becomes a longer lever to generate more power in kicking techniques, and a longer striking distance than the opponent provides advantage in order to reach the scoring area (De la Fuente \& Gómez-Landero Rodríguez, in press; Kazemi, Waalen, Morgan, \& White, 2006; Markovic, Misigoj-Durakovic, \& Trninic, 2005). Related to this idea, authors like Bridge et al., (2014), Kazemi et al. (2013), Pieter (2010), Kazemi et al. (2006) and Markovic et al. (2005) have reported that more successful athletes are taller than their regular counterparts.

Dubnov-Raz et al. (2015) have studied the relationship between height and weight in karate athletes, dividing them into hypothetical height categories and hypothetical weight categories and calculating how many participants fit into corresponding divisions of both categorizations. Their results demonstrate that height categories could be used as an alternative to weight categories for pediatric ages, because most athletes maintain a similar category (with potential opponents of approximately equal weight) if divided by height. However, karate and TKD athletes have characteristics that are slightly different in general terms, especially as regards somatotype aspects, as TKD athletes are more ectomorph than their karate counterparts (Bridge et al., 2014; Chaabène, Hachana, Franchini, Mkaouer, \& Chamari, 2012). In addition, the present study proposes a height classification according to World Health Organization (WHO) guidelines (WHO, 2007).

\section{Methods}

\subsection{Participants}

The study sample is composed of 153 male $(n=80)$ and female $(n=73)$ competitive TKD athletes aged between 10 and 16. All of them were competitors in Kyorugui (combat Olympic modality) and had more than two years' experience in official championships. All the subjects and their legal guardians signed a written informed consent, in accordance with the procedures of this investigation and the publication of the data obtained. Ethical approval for this research was obtained from the University's Human Research Ethics Committee.

\subsection{Measures}

The height of the athletes was measured by a wall-mounted stadiometer (SECA 222, SECA gmbh, Hamburg, Germany), obtaining values to the nearest $0.1 \mathrm{~cm}$. Subjects were barefoot and with their feet and knees joined; heels, gluteus shoulders, and head touching the wall, and head correctly aligned in the Frankfort plane, according to the International Society for the Advancement of Kinanthropometry (ISAK) guidelines for measurement of standing height (Marfell-Jones et al., 2006). For the body mass data, subjects were individually weighed barefoot and wearing shorts and t-shirt, using calibrated scales to the nearest $0.1 \mathrm{~kg}$ (SECA 635, SECA gmbh, Hamburg, Germany).

\subsection{Design and Procedures}

As in general with other combat sports, in TKD competitions athletes are categorized by age, sex, and weight. At these young ages, ten weight categories are officially established for each age group (pre-cadets, cadets, and juniors), in increments of between 2 and $5 \mathrm{~kg}$ (approximately $4.5-7.5 \%$ of body mass), depending on progression (in low-weight categories, increments between 
limits are lower than in high-weight categories) (World Taekwondo Federation, WTF, 2016). The pre-cadet category is the only non-official category at international level, but there are official national championships for this age group.

All measurements for each athlete were carried out on a sole session, and subjects were members of different TKD clubs from Spain visited on the same month. When data were collected, subjects were divided by age and sex, in order to compare data between athletes who could potentially be opponents in official competition. First, each athlete was classified within one of ten official weight categories for their age and sex. Next, athletes were sorted for this investigation into ten hypothetical height categories of increments of between 5 and $7 \mathrm{~cm}$ established in every age and sex group, according to WHO percentiles for each age and sex (WHO, 2007), based on data from the growth charts for the United States (Kuczmarski et al., 2002). Height and weight categories were numbered from 1 (lowest) to 10 (highest) (Tables 1, 2, and 3).

Table 1. Weight official and height proposal categorization for pre-cadet athletes (8-11 years old, both included).

\begin{tabular}{ccccc}
\hline Category & $\begin{array}{c}\text { Weight official } \\
\text { division (males) }\end{array}$ & $\begin{array}{c}\text { Height division } \\
\text { (males) }\end{array}$ & $\begin{array}{c}\text { Weight official } \\
\text { division (females) }\end{array}$ & $\begin{array}{c}\text { Height division } \\
\text { (females) }\end{array}$ \\
\hline 1 & $<27 \mathrm{~kg}$ & $<117 \mathrm{~cm}$ & $<27 \mathrm{~kg}$ & $<118 \mathrm{~cm}$ \\
2 & $27.1-30 \mathrm{~kg}$ & $117.1-123 \mathrm{~cm}$ & $27.1-30 \mathrm{~kg}$ & $118.1-124 \mathrm{~cm}$ \\
3 & $30.1-33 \mathrm{~kg}$ & $123.1-129 \mathrm{~cm}$ & $30.1-33 \mathrm{~kg}$ & $124.1-130 \mathrm{~cm}$ \\
4 & $33.1-36 \mathrm{~kg}$ & $129.1-135 \mathrm{~cm}$ & $33.1-36 \mathrm{~kg}$ & $130.1-136 \mathrm{~cm}$ \\
5 & $36.1-40 \mathrm{~kg}$ & $135.1-141 \mathrm{~cm}$ & $36.1-40 \mathrm{~kg}$ & $136.1-142 \mathrm{~cm}$ \\
6 & $40.1-44 \mathrm{~kg}$ & $141.1-147 \mathrm{~cm}$ & $40.1-44 \mathrm{~kg}$ & $142.1-148 \mathrm{~cm}$ \\
7 & $44.1-48 \mathrm{~kg}$ & $147.1-153 \mathrm{~cm}$ & $44.1-48 \mathrm{~kg}$ & $148.1-154 \mathrm{~cm}$ \\
8 & $48.1-52 \mathrm{~kg}$ & $153.1-159 \mathrm{~cm}$ & $48.1-52 \mathrm{~kg}$ & $154.1-160 \mathrm{~cm}$ \\
9 & $52.1-57 \mathrm{~kg}$ & $159.1-165 \mathrm{~cm}$ & $52.1-57 \mathrm{~kg}$ & $160.1-166 \mathrm{~cm}$ \\
10 & $>57 \mathrm{~kg}$ & $>165 \mathrm{~cm}$ & $>57 \mathrm{~kg}$ & $>166 \mathrm{~cm}$ \\
\hline
\end{tabular}

Table 2. Weight official and proposed height categorization for cadet athletes (12-14 years old, both included).

\begin{tabular}{ccccc}
\hline Category & $\begin{array}{c}\text { Weight official } \\
\text { division (males) }\end{array}$ & $\begin{array}{c}\text { Height division } \\
\text { (males) }\end{array}$ & $\begin{array}{c}\text { Weight official } \\
\text { division (females) }\end{array}$ & $\begin{array}{c}\text { Height division } \\
\text { (females) }\end{array}$ \\
\hline 1 & $<33 \mathrm{~kg}$ & $<129 \mathrm{~cm}$ & $<29 \mathrm{~kg}$ & $<131 \mathrm{~cm}$ \\
2 & $33.1-37 \mathrm{~kg}$ & $129.1-136 \mathrm{~cm}$ & $29.1-33 \mathrm{~kg}$ & $131.1-137 \mathrm{~cm}$ \\
3 & $37.1-41 \mathrm{~kg}$ & $136.1-143 \mathrm{~cm}$ & $33.1-37 \mathrm{~kg}$ & $137.1-143 \mathrm{~cm}$ \\
4 & $41.1-45 \mathrm{~kg}$ & $143.1-150 \mathrm{~cm}$ & $37.1-41 \mathrm{~kg}$ & $143.1-149 \mathrm{~cm}$ \\
5 & $45.1-49 \mathrm{~kg}$ & $150.1-157 \mathrm{~cm}$ & $41.1-44 \mathrm{~kg}$ & $149.1-155 \mathrm{~cm}$ \\
6 & $49.1-53 \mathrm{~kg}$ & $157.1-164 \mathrm{~cm}$ & $44.1-47 \mathrm{~kg}$ & $155.1-161 \mathrm{~cm}$ \\
7 & $53.1-57 \mathrm{~kg}$ & $164.1-171 \mathrm{~cm}$ & $47.1-51 \mathrm{~kg}$ & $161.1-167 \mathrm{~cm}$ \\
8 & $57.1-61 \mathrm{~kg}$ & $171.1-178 \mathrm{~cm}$ & $51.1-55 \mathrm{~kg}$ & $167.1-173 \mathrm{~cm}$ \\
9 & $61.1-65 \mathrm{~kg}$ & $178.1-185 \mathrm{~cm}$ & $55.1-59 \mathrm{~kg}$ & $173.1-179 \mathrm{~cm}$ \\
10 & $>65 \mathrm{~kg}$ & $>185 \mathrm{~cm}$ & $>59 \mathrm{~kg}$ & $>179 \mathrm{~cm}$ \\
\hline
\end{tabular}

Table 3. Weight official and proposed height categorization for junior athletes (15-17 years old, both included).

\begin{tabular}{ccccc}
\hline Category & $\begin{array}{c}\text { Weight official } \\
\text { division (males) }\end{array}$ & $\begin{array}{c}\text { Height division } \\
\text { (males) }\end{array}$ & $\begin{array}{c}\text { Weight official } \\
\text { division (females) }\end{array}$ & $\begin{array}{c}\text { Height division } \\
\text { (females) }\end{array}$ \\
\hline 1 & $<45 \mathrm{~kg}$ & $<148 \mathrm{~cm}$ & $<42 \mathrm{~kg}$ & $<142 \mathrm{~cm}$ \\
2 & $45.1-48 \mathrm{~kg}$ & $148.1-154 \mathrm{~cm}$ & $42.1-44 \mathrm{~kg}$ & $142.1-147 \mathrm{~cm}$ \\
3 & $48.1-51 \mathrm{~kg}$ & $154.1-160 \mathrm{~cm}$ & $44.1-46 \mathrm{~kg}$ & $147.1-152 \mathrm{~cm}$ \\
4 & $51.1-55 \mathrm{~kg}$ & $160.1-166 \mathrm{~cm}$ & $46.1-49 \mathrm{~kg}$ & $152.1-157 \mathrm{~cm}$ \\
5 & $55.1-59 \mathrm{~kg}$ & $166.1-172 \mathrm{~cm}$ & $49.1-52 \mathrm{~kg}$ & $157.1-162 \mathrm{~cm}$ \\
6 & $59.1-63 \mathrm{~kg}$ & $172.1-178 \mathrm{~cm}$ & $52.1-55 \mathrm{~kg}$ & $162.1-167 \mathrm{~cm}$ \\
7 & $63.1-68 \mathrm{~kg}$ & $178.1-184 \mathrm{~cm}$ & $55.1-59 \mathrm{~kg}$ & $167.1-172 \mathrm{~cm}$ \\
8 & $68.1-73 \mathrm{~kg}$ & $184.1-190 \mathrm{~cm}$ & $59.1-63 \mathrm{~kg}$ & $172.1-177 \mathrm{~cm}$ \\
9 & $73.1-78 \mathrm{~kg}$ & $190.1-196 \mathrm{~cm}$ & $63.1-68 \mathrm{~kg}$ & $177.1-182 \mathrm{~cm}$ \\
10 & $>78 \mathrm{~kg}$ & $>196 \mathrm{~cm}$ & $>68 \mathrm{~kg}$ & $>182 \mathrm{~cm}$ \\
\hline
\end{tabular}




\subsection{Statistical analysis}

The Pearson's correlation coefficient was used to measure the relationship between height and weight of the athletes, taking their raw value (without categorization). To examine the correlation between height (created) and weight (official) categorization, subjects were classified into categories (named with numbers from 1 to 10, as showed in tables 1-3) according to both characteristics separately, taking the height category to which athlete belongs as variable one, and the weight category to which athlete belongs as variable two (e.g. a male junior athlete who weighs $46 \mathrm{~kg}$ and is $150 \mathrm{~cm}$ tall was include in weight category number 2 and height category number 2). Then, correlation between height and weight categories was calculated through Pearson's correlation coefficient, comparing athletes' inclusion in one in relation to the other.

In addition, how many athletes agreed with the corresponding categories of both height and weight categories (e.g., athlete classified in weight category 1 and height category 1), or were near (e.g., athlete classified in weight category 3 and in height category 2 or 4 , and vice versa) was calculated. All statistical analyses were performed using IBM SPSS Statistics for Windows (v. 22).

\section{Results}

Descriptive data of the whole study population are presented in Table 4 . There was a strong correlation between height and weight variables in the whole sample $(r=0.843, p<0.01)$

Table 4. Descriptive statistics of study participants.

\begin{tabular}{lc}
\hline Variable & $\boldsymbol{M} \pm \boldsymbol{S} \boldsymbol{D}$ \\
\hline Age (years old) & $12,34 \pm 1,88$ \\
Height $(\mathrm{cm})$ & $156,24 \pm 10,73$ \\
Body mass $(\mathrm{kg})$ & $47,40 \pm 10,14$ \\
\hline
\end{tabular}

Table 5 presents the distribution of all study participants according to both height and weight categories, in order to show how many athletes would remain in the same category when divided by height instead of official weight categories, or how many athletes would be in a category immediately higher or lower. According to these data, $22.77 \%$ of athletes remained in the same category by height rather than weight, while $68.18 \%$ of participants moved only \pm 1 category by height from their original weight category. There was a good correlation between height and weight proposed categories in the whole study sample $(r=0.681, p<0.01)$.

Table 5. Distribution of athletes according to both height and weight categorization.

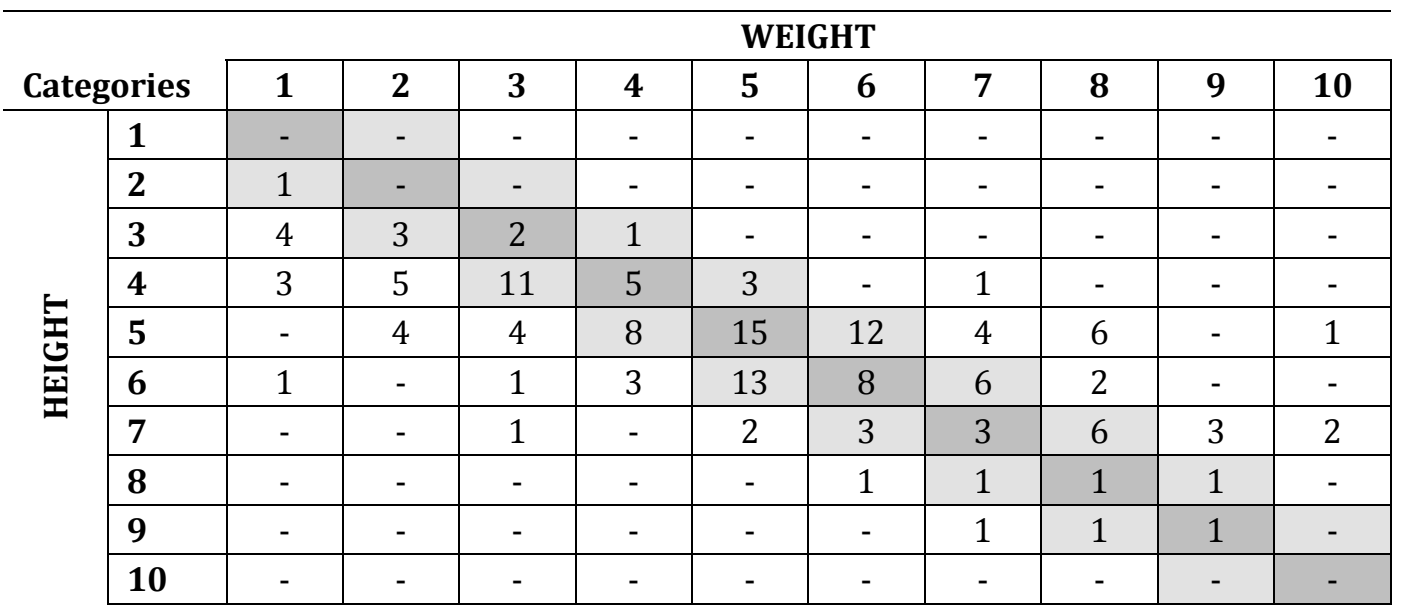

\section{Discussion}

The aim of this study was to examine the relationship between a newly proposed height categorization and the official weight categorization in young competitive TKD fighters, in order to determine if the proposed height categories could be used in TKD competitions as a healthier alternative to weight categories for young athletes. 
According to the the fact that height is considered a predisposing factor for succees in TKD (Bridge et al., 2014; Kazemi et al., 2013; Kazemi et al., 2006), due to it allows a longer striking distance and longer lever to generate power (De la Fuente \& Gómez-Landero Rodríguez, In press; Kazemi et al., 2006; Markovic et al., 2005), forgetting height as a categorization factor may contribute to a fight inequality, resulting in a disadvantageous system for smaller athletes.

Traditionally, athletes are categorized by weight, attending to body mass is the determinant factor when it comes to confronting athletes to fight body to body. However, technical differences between combat sports should be considered for competition categorization. While grappling sports like judo and wrestling involve the manipulation of an opponent's body mass, striking sports like TKD and boxing consist of techniques based on one's own body mass movement. So in these sports where specific techniques for scoring are not necessary to move or displace the opponent's body, perhaps a different body mass between athletes is not the main distinctive characteristic (Reale et al., 2016, 2017). In addition, studies like that by Estevan et al. (2012) and Falcó et al. (2011) reported that athletes of different official weight divisions do not generate impact forces which are significantly different. Thus, fighting against a slightly heavier opponent would not involve any disadvantage in terms of achieving points and receiving impacts. Contrary to grappling combat sports, it seems that body mass is not a distinctive factor in order to achieve points in kicking sports such as TKD.

Based on the previous information, it could be inferred that categorizing TKD athletes without paying attention to height leads to more unbalanced fights than categorization by body mass. In addition, the present investigation shows that there was a good correlation between athletes' height category and weight category, demonstrating that distributing athletes by height in TKD fights is not extremely inequitable in body mass terms.

The extremely high frequency of disordered eating behaviors associated with combat sports is largely related to acute weight loss prior to competition (Brito et al., 2012; Dubnov-Raz et al., 2015; Langan-Evans et al., 2011), and the negative effects, both in competition performance and athlete health, are thoroughly described (Franchini et al., 2012; Kazemi et al., 2011; Koral \& Dosseville, 2009; Langan-Evans et al., 2011; Steen \& Brownell, 1990). These rapid weight loss procedures can induce psychological difficulties such as decreased memory, difficulty in concentrating, enhanced fatigue and confusion, anxiety, decreased vigor, and even depression and isolation (Franchini et al., 2012; Kazemi et al., 2011; Koral \& Dosseville, 2009; Steen \& Brownell, 1990). With reference to physiological factors, pre-competition acute weight loss can lead to a dehydration state that causes cardiological disturbances, decreased muscular performance because of muscle glycogen depletion, and other effects, such as impaired immunity and altered thermoregulation (Franchini et al., 2012) or even death (Franchini et al., 2012; Kazemi et al., 2011). Attending to this, and to the good correlation between athletes' height category and weight category observed in the present investigation, categorizing athletes by height in TKD competition could maybe reduce these unhealthy practices without bringing new physical disadvantages between athletes.

Furthermore, if categorization is made according to a modifiable factor, like weight, athletes can try to extremely modify their body characteristics in order to gain some advantage. Nowadays, that is indeed what they do. This is the main reason because any other possible categorization by modifiable factors, like body mass index (BMI), have not been used in the present study, but its rejection as categorization factor has not been supported by empirical evidence. However, if competition division is according to non-modifiable factors, like age, sex, and height, as we propose in the present study, athletes would concentrate their efforts on developing their athletic capacities and sport-specific abilities. Training practices and coaches' knowledge may be more relevant for sports performance. TKD athletes, if divided by height categories, would direct their training towards being the most athletic for their height, instead of trying to be as thin as possible.

\section{Conclusion}

The aim of this study was to examine the relationship between a height categorization and the official weight categorization in young competitive TKD fighters, in order to determine if the 
proposed height categories could be used in TKD competitions as a healthier alternative to weight categories for young athletes. The results showed a close relationship between both variables, so young competitive TKD athletes can be categorized by height in official competition without big disadvantages in terms of body mass. It is suggested that height categories can be used as a healthier alternative to current weight divisions in official competition. Thus, eating disorders in combat sports athletes could be reduced, and fights would be more equitable according to kicking combat sports characteristics.

The main limitations of the current research were the non-inclusion of complementary variables for the statistical analysis, like BMI or leg length, which maybe enriching significantly the obtained results. Also, specific sample by age should be analyzed separately in future studies, in order to know if some ages are more sensitive to inequalities when categorization is made by height. Further research is needed to ensure the feasibility of include height categorization in official competition.

\section{Acknowledgements}

The author would like to thank coach José María Martín del Campo for helping with logistic aspects of this investigation, and Egoitz Sánchez for helping with subjects and data collection.

\section{References}

Bridge, C. A., Ferreira Da Silva Santos, J., Chaabène, H., Pieter, W., \& Franchini, E. (2014). Physical and physiological profiles of Taekwondo athletes. Sports Medicine, 44(6), 713-733. doi: 10.1007/s40279-014-0159-9

Brito, C. J., Roas A, F. C. M., Brito I, S. S., Marins J, C. B., Córdova, C., \& Franchini, E. (2012). Methods of body mass reduction by combat sport athletes. International Journal of Sport Nutrition and Exercise Metabolism, 22(2), 89-97. doi: 10.1123/ijsnem.22.2.89

Chaabène, H., Hachana, Y., Franchini, E., Mkaouer, B., \& Chamari, K. (2012). Physical and physiological profile of elite karate athletes. Sports Medicine, 42(10), 829-843. doi: 10.2165/11633050-000000000-00000

Constantini, N. W., Mashiach, Y., Arieli, R., \& Dubnov-raz, G. (2011). Prevalence and Techniques of Pre-competition Rapid Weight Loss in Young Taekwondo Fighters. Medicine \& Science in Sports \& Exercise, 43(suppl 1-5), 473. doi: 10.1249/01.MSS.0000401306.27164.75

De la Fuente, A., \& Gómez-Landero Rodríguez, L. A. (in press). Motor differences in cadet taekwondo athletes according to competition level. Revista Internacional de Medicina y Ciencias de la Actividad Física $\quad y \quad$ el Deporte. Retrieved from http://cdeporte.rediris.es/revista/inpress/artdiferencias1002e.pdf

Dubnov-Raz, G., Mashiach-Arazi, Y., Nouriel, A., Raz, R., \& Constantini, N. W. (2015). Can height categories replace weight categories in striking martial arts competitions? A pilot study. Journal of Human Kinetics, 47(1), 91-98. doi: 10.1515/hukin-2015-0065

Estevan, I., Falco, C., Álvarez, O., \& Molina-García, J. (2012). Effect of olympic weight category on performance in the roundhouse kick to the head in Taekwondo. Journal of Human Kinetics, 31(1), 37-43. doi: 10.2478/v10078-012-0004-x

Falcó, C., Estevan, I., Álvarez, O., \& Molina-García, J. (2011). Capacidad de generación de fuerzas de golpeo y tiempo de ejecución según la categoría de peso en taekwondo. e-balonmano.com: Revista de Ciencias del Deporte, 7(supl.), 23-29. Retrieved from http://www.ebalonmano.com/ojs/index.php/revista/article/view/70

Franchini, E., Brito, C. J., \& Artioli, G. G. (2012). Weight loss in combat sports: Physiological, psychological and performance effects. Journal of the International Society of Sports Nutrition, 9, 2-7. doi: 10.1186/1550-2783-9-52

Kazemi, M., De Ciantis, M. G., \& Rahman, A. (2013). A profile of the Youth Olympic Taekwondo Athlete. The Journal of the Canadian Chiropractic Association, 57(4), 293-300. Retrieved from https://www.ncbi.nlm.nih.gov/pmc/articles/PMC3845466/

Kazemi, M., Rahman, A., \& De Ciantis, M. (2011). Weight cycling in adolescent Taekwondo athletes. Journal of the Canadian Chiropractic Association, 55(4), 318-324. Retrieved from https://www.ncbi.nlm.nih.gov/pmc/articles/PMC3222708/ 
Kazemi, M., Waalen, J., Morgan, C., \& White, A. R. (2006). A profile of Olympic Taekwondo competitors. Journal of Sports Science and Medicine, 5(CSSI-1), 114-121. Retrieved from https://www.ncbi.nlm.nih.gov/pmc/articles/PMC3863920/

Klump, K. L. (2014). Puberty as a Critical Risk Period for Eating Disorders: A Review of Human and Animal Studies. Hormones and Behaviour, 64(2), 399-410. doi: 10.1016/i.yhbeh.2013.02.019.Puberty

Koral, J., \& Dosseville, F. (2009). Combination of gradual and rapid weight loss: Effects on physical performance and psychological state of elite judo athletes. Journal of Sports Sciences, 27(2), 115-120. doi: 10.1080/02640410802413214

Kuczmarski, R. J., Ogden, C. L., Guo, S. S., Grummer-Strawn, L. M., Flegal, K. M., Mei, Z., ... Johnson, C. L. (2002). 2000 CDC Growth Charts for the United States: methods and development. Vital and Health Statistics. Series 11, Data from the National Health Survey, (246), 1-190.

Langan-Evans, C., Close, G. L., \& Morton, J. P. (2011). Making Weight in Combat Sports. Strength and Conditioning Journal, 33(6), 25-39. doi: 10.1519/SSC.0b013e318231bb64

Markovic, G., Misigoj-Durakovic, M., \& Trninic, S. (2005). Fitness Profile of Elite Croatian Female Taekwondo Athletes. Collegium Antropologicum, 29(1), 93-99. Retrieved from https://www.ncbi.nlm.nih.gov/pubmed/16117305

Pieter, W. (2010). Talent detection in taekwondo practitioners. Revista de Artes Marciales Asiáticas, 5(2), 77-96. doi: http://dx.doi.org/10.18002/rama.v5i2.112

Reale, R., Slater, G., \& Burke, L. M. (2016). Acute Weight Loss Strategies for Combat Sports and Applications to Olympic Success. International Journal of Sports Physiology and Performance, 12, 142-151. doi: 10.1123/ijspp.2016-0211

Reale, R., Slater, G., \& Burke, L. M. (2017). Individualised dietary strategies for Olympic combat sports: Acute weight loss, recovery and competition nutrition. European Journal of Sport Science, 17(6), 727-740. doi: 10.1080/17461391.2017.1297489

Silva Santos, J. F. da, Takito, M. Y., Artioli, G. G., \& Franchini, E. (2016). Weight loss practices in Taekwondo athletes of different competitive levels. Journal of Exercise Rehabilitation, 12(3), 202-208. doi: $10.12965 /$ jer.1632610.305

Steen, S. N., \& Brownell, K. D. (1990). Patterns of weight loss and regain in wrestlers: has the tradition changed? Medicine and Science in Sports and Exercise, 22(6), 762-768. Retrieved from https://journals.lww.com/acsm$\underline{\text { msse } / \text { pages } / \text { articleviewer.aspx } \text { ?year }=1990 \& i s s u e=12000 \& \text { article }=00005 \& \text { type }=\text { abstract }}$

World Health Organization (2007). Growth reference data for 5-19 years. Retrieved from http://www.who.int/growthref/who2007 height for age/en/

World Taekwondo Federation (2016). Competition Rules and Interpretation. Retrieved from http://www.worldtaekwondofederation.net/rules-and-documents

\section{Author's biographical data}

Ana de la Fuente (Spain). MSc Physical and Sport Performance, Universidad Pablo de Olavide, 2014-2015. BSc Sport Sciences, Universidad Autónoma de Madrid, 2010-2014. BSc Physical Therapy, Universidad Complutense de Madrid, 2014-2018. 1 ${ }^{\text {st }}$ DAN Taekwondo WTF. Taekwondo coach 2014-2018. Rehab \& Fitness coach in CDE Sánchez Élez, Sanabria Taekwondo Club, 2016-2018. Taekwondo athlete, European Sub21 Bronze medal 2010. E-mail: ana.delafuente@hotmail.com 